\title{
CYTOTOXICITY, BIOCHEMICAL EFFECT AND ENVIRONMENTAL IMPACT OF MONENSIN ON DAIRY CATTLE
}

\author{
ELALFY MOHAMED MAHMOUD*; ABDALLAH AHMED ABDNASER ${ }^{* *}$ and \\ SLEEM RADWAN FATHY ${ }^{* * *}$ \\ * Lecturer of Forensic Medicine and Toxicology, Faculty of Veterinary Medicine, Mansoura University, Egypt \\ *** Phd Veterinary Doctor, Department of Internal Medicine, at Sha-Veterinary Hospital \\ *** Prof. of Forensic Medicine and Toxicology, Faculty of Veterinary Medicine, Mansoura University, Egypt \\ Email: dr_melalfym@yahoo.com \\ Assiut University web-site: www.aun.edu.eg
}

\begin{abstract}
Received at: $21 / 4 / 2015$

Rumensin (monensin) is the first ionophore to be approved by the Food and Drug Administration (FDA) for increased milk production efficiency. Monensin treatment at dose of $10 \mathrm{gm} /$ ton in total mixed ration lead to increase both milk production and body weight through its effect on increase feed digestibility, microbial digestion and also decrease losses of nitrogen in feces which lead to decrease environmental hazards of nitrogen on both animal and public health. More over there is no cytotoxicity recorded due to monensin treatment at dose of $10 \mathrm{gm} / \mathrm{ton}$. Monensin treated animals showed significant increase in total protein serum level, globulin serum level, urea serum level, and cholesterol serum level level while had no effect on albumin, total bilrubin and glucose serum levels. Taken together, monensin is safe for use in dairy animals and has an environmental impact role.
\end{abstract}

Key words: Cytotoxicity, Monensin, Dairy Cattle, Biochemical Effect.

\section{INTRODUCTION}

In 2050, we will need to increase the food production by $100 \%$ to be enough for population over the world. so we need to increase the production of food especially of animal source through the use of advanced technology. Important one is growth promoting agent and biologcal gene modulation of animal breeds although, European and Egyptian laws refuse completely the use of hormones.

Rumensin (monensin) is the first ionophore to be approved by the Food and Drug Administration (FDA) for increased milk production efficiency (production of marketable $4.0 \%$ solids-corrected milk per unit of feed intake) when fed to dairy cows. Monensin is an ionophore widely used in the dairy cattle industry throughout the world end especially in germany (Emmerich et al., 2013). More over, there are many clinical experiments indicated that Monensin explored efficacy for various metabolic, production, and health outcomes of dairy cattle (Duffield et al., 2012) and a number of investigations have demonstrated that monensin increases milk yield when fed to cows offered mixed grain and forage diets (Granzin and Dryden, 1999 and Dubuc et al., 2010).
The dairy industry has improved the efficiency of milk production over the years. Total mixed rations and other factors had led to a more than four fold increase in milk production per cows since 1940. However, the feed required for production of that milk only increased two fold. These changes led to a doubling in the efficiency of milk production. However, milk production efficiency (MPE) as a metric, is not commonly measured like feed conversion is in other livestock enterprises. For example, in the U.S. A. about $95 \%$ of the cattle in feedlots fed rumensin in their rations (Raun, 1990).

Sodium monensin, an ionophore antibiotic produced by Streptomyces cinnamonensis had many benefits such as modified the ruminal flora (Hamilton et al., 2010 and McGarvey et al., 2010) and improved the digestive efficiency of cattle. The effects of monensin supplementation include increased ruminal propionate production, reduced in vivo and in vitro production of methane, increased dry matter and starch digestibility, decreased production of bacterial protein in the rumen, increased nitrogen retention and significantly increased flow of amino acids to the duodenum and digestion of amino acids in the duodenum. A decreased ruminal turnover rate and increased rates of ruminal fill have been noted with treatment and 
monensin can modify the flux of ions across epithelial cells of the intestine and increase the uptake of calcium, selenium, and other cations. The treatment of lactating dairy cows with monensin has resulted in increased plasma glucose concentrations and decreased plasma ketone concentrations. The capacity of monensin to alter metabolism suggests that the effects of monensin treatment on reproduction, health, and production of dairy cows require further investigation (Beckett et al., 1998).

There are a closely link between the amount of feed consumed and amount of milk production (Britt et al., 2004).

More over, Series of several conducted mutagenicity studies was provided (Ames, chromosome aberration test in vitro and a micronucleus test in vivo) that Monensin was negative in the Ames test, was not clastogenic in vitro and did not increase the incidence of micronucleated cells in vivo.

While in the in vitro cytogenetic assay the relevelance diplochromosomes remained unclear (Veterinary medicine and European medicine agency, 2007). The rational of this study to investigate the cytotoxicity and safety of monensin use for dairy cattle.

\section{MATERIALS and METHODS}

\section{I- Materials.}

1) Rumensin ${ }^{\mathrm{R}}$.
Rumensin was kindly obtained from Elanco Company for pharmaceutical preparation, Egypt.

Common name. Monensin

Trade name. Rumensin

Chemical name. sodium (2R,3S,4S)-4[(2R,5R,7S,8R,9S)-2-[(2R,5S)-5-ethyl-5-[(2S,3R,5S)5-[(2S,3S,5R,6S)-6-hydroxy-6-(hydroxymethyl)-3,5dimethyl-oxan-2-yl]-3-methyl-oxolan-2-yl]oxolan-2yl]-9-hydroxy-2,8-dimethyl-1,6dioxaspiro[4.5]decan-7-yl]-3-methoxy-2-methylpentanoate

\section{2)- Kits.}

1. Total protein kits (dp international)

2. Albumin kits (Dimond Diagnostics).

3. Glucose kits (Spinreact)

4. Urea kits (Dimond Diagnostics)

5. Cholesterol kits (Spinreact)

6. Total bilirubin Kits (APC Diagnostics)

\section{3)- Equipments.}

Spectrophotometer (Hang Fen 7230, china)

Automatic pipettes

\section{4) Experimental animals.}

this experiments in his dairy farm on Damita governorate on 20 Holstein dairy cow, after first delivery were fed on total mixed ration (TMR) which consists of silage, corn, soy bean, cotton seed cake, hay, mineral mixtures and vitamins mixtures

Total mixed ration (TMR)

Table 1: Ingredients, composition, of the experimental total mixed ration (TMR) for experimental cows.

\begin{tabular}{ll}
\hline & TMR \\
\hline Ingredient \% of DM & \\
\hline silage & 38.39 \\
\hline corn & 12.79 \\
\hline Soy bean meal & 11.9 \\
\hline Cotton seed cake & 15.3 \\
\hline hay & 21.3 \\
\hline Mineral mixtures & 0.08 \\
\hline Vitamins mixtures & 0.08 \\
\hline
\end{tabular}

Ration was done according nutrient requirements of dairy Cattle animal needs during lactation period especially energy and protein ratio (NRC., 2001)

\section{Methods}

Monensin treated animals.

We examined the effects of monensin on feed intake and milk production in 10 Holstein cows fed total mixed ration supported with monensin while the other
10 Holstein cows fed total mixed ration without monensin. Diets were fed for ad libitum intake four times a day and water was also available for ad libitum intake. The experimental period lasted $3 \mathrm{wks}$ and comprised 2 wks of adaptation to monensin, as rec- 
ommended by Thornton and Owens (1981), and 3 wks of experimental observations. The daily individual dose of the monensin premix was mixed with 140 $\mathrm{g}$ of Soy bean meal at dose of $10 \mathrm{~g} /$ ton and then added to the diet of the specific cows. The cows were milked twice daily and milk production of each cows was recorded daily. Blood samples were collected into sterile tubes for separation of serum and isolation of Buffy coat for culturing of lymphocyte. Serum was analyzed for urea, glucose, cholesterol, total bilirubin, total protein and albumin levels.

\section{Biochemical analysis.}

a- Determination of serum total protein was determined according to the method of Henery (1964).

b- Determination of serum albumin was determined according to the method of Doumnas et al. (1971).

c- Determination of serum glucose level.was determined according to the method of Kaplan (1984).

d- Determination of serum bilirubin level was determined according to the method of Jendrassik and Grof (1938).

g- Determination of serum urea level was determined according to the method of Patton and Crouch (1977).

h- Determination of serum cholesterol level was determined according to the method of Naito and Kaplan (1984).

2- Weighting of animals before and after treatment to assess effect of monensin on body weights.

3- Weighting of daily milk yield of each animals to assess effect of monensin on milk yield.

\section{Determination of Chromosomal Aberrations in} cultured lymphocyte

Blood cells from dairy cows fed on diet enriched by monensin were cultured for $72 \mathrm{~h}$ at $38^{\circ} \mathrm{C}$ in $5 \mathrm{~mL}$ TCM-199, $1 \mathrm{~mL}$ fetal calf serum and $0.1 \mathrm{~mL}$ phytohaemagglutinin (PHA). After incubation, cells were treated with colchicines $(0.05 \%)$ for $2 \mathrm{~h}$, then with a hypotonic $(0.075 \mathrm{M} \mathrm{KCl})$ for $30 \mathrm{~min}$. After fixation in acetic acid. ethanol (1.3) solution, the cells suspensions were dropped on wet slides then flamed to dry. The slides were stained with Giemsa stain and covered with DPX mounting media for chromosomal analysis. Chromosomal abnormalities were recorded in at least 50 metaphase spreads for each animal

\section{Statistical analysis.}

Data obtained in this study were statistically analyzed for student T-test

\section{RESULTS}

\section{1- Biochmical changes due to administration of monensin}

Monensin treated animals showed significant increase in total protein serum level, globulin serum level, urea serum level and cholesterol serum level when compared with control group while had no effect on total bilrubin, serum level albumin and glucose serum levels when compared with control group. The present study found that monensin improved the productivity of animal through increase immunity levels, especially high level of globulin and avoid the animal sub-clinical infection. More over, increase the serum protein level is very important for milk production. Additionally, There is no effect of monensin on glucose level and these results could attributed to glucose precursors, primarily propionate and amino acids, become essential for a successful lactation. Most of this glucose is produced by liver, and propionate is the single largest contributor to liver glucose production. Glucose synthesis must increase to meet the needs of lactose synthesis. These results illustrated in table (2) and fig (1)

2. Effect of administration of monensin on both body weights and daily milk yield

There was a significant increase in body weight of dairy cows treated with monensin and this result could be attributed to Monensin shifts the microbial population in the rumen by promoting the growth of more efficient bacteria involved in carbohydrate metabolism. This results in an increase in propionate production in the rumen Thus, more energy is obtained from every pound of feed. Also increase feed efficiency through increase feed digestibility and greater supply of bypass protein to the small intestine and a subsequent increase in the use of absorbed nonessential AA for gluconeogenesis. This would lead to a rise in deamination of these AA and higher concentration of BUN.

From environmental view, monensin supplementation increased ruminal propionate production and subsequently propionate reduced in vivo and in vitro production of methane. So monensin is useful for safety of environment and prevents environmental sharp change. These results illustrated in table (3) and fig (2).

\section{Estimation of chromosomal aberration of culti- vated lymphocyte \\ The present study showed that lymphocyte of dairy cattle treated with monensin showed no chromosomal aberration at dose of $10 \mathrm{gm} / \mathrm{ton}$. More over there was no diplochromosomes.}


$\underline{\text { Assiut Vet. Med. J. Vol. } 61 \text { No. } 146 \text { July } 2015}$

Table 2: Showing biochemical changes due to monesin administration at dose of $10 \mathrm{gm} /$ ton for dairy cows.

\begin{tabular}{cccccccc}
\hline & $\begin{array}{c}\text { Total protein } \\
\mathrm{g} / \mathrm{dl}\end{array}$ & Albumin & Globulin & Urea & Glucose & Cholesterol & $\begin{array}{c}\text { Total Bilirubin } \\
\mathrm{mg} / \mathrm{dl}\end{array}$ \\
& & $\mathrm{g} / \mathrm{dl}$ & $\mathrm{g} / \mathrm{dl}$ & $\mathrm{mg} / \mathrm{dl}$ & $\mathrm{mg} / \mathrm{dl}$ & $\mathrm{mg} / \mathrm{dl}$ & \\
& T vs C & T vs C & T vs C & T vs C & T vs C & T vs C & T vs C \\
\hline Mean & $31.8^{\mathrm{a}} 18.8^{\mathrm{b}}$ & $4.41^{\mathrm{a}} 4.1^{\mathrm{a}}$ & $27.8^{\mathrm{a}} 14.7^{\mathrm{b}}$ & $50.4^{\mathrm{a}} 39.5^{\mathrm{b}}$ & $61^{\mathrm{a}} 59.9^{\mathrm{a}}$ & $239.8^{\mathrm{a}} 190^{\mathrm{b}}$ & $20.8^{\mathrm{a}} 20.7^{\mathrm{a}}$ \\
\hline S. E. & $\pm 1.3 \pm 0.28$ & $\pm 0.8 \pm 0.34$ & $\pm 3.89 \pm 0.98$ & $\pm 3.8 \pm 1.5$ & $\pm 1.1 \pm 0.4$ & $\pm 17.8 \pm 11.8$ & $\pm 0.5 \pm 0.5$ \\
\hline
\end{tabular}

A, b, c, d. Different letters are significantly different between groups at $\mathrm{P} \leq 0.01 \%$

Table 3: Showing the effect of monensin adminsitration at dose of $10 \mathrm{gm} / \mathrm{ton}$ on body weights and milk yeild of dairy cows

\begin{tabular}{|c|c|c|c|c|c|}
\hline & \multicolumn{2}{|c|}{ Body weights } & \multicolumn{3}{|c|}{ Milk yeild } \\
\hline & $\mathrm{T}$ & vs & $\mathrm{T}$ & vs & $\mathrm{C}$ \\
\hline Mean & $565.5^{\mathrm{a}}$ & $482.5^{\mathrm{b}}$ & $23.7^{\mathrm{a}}$ & & $20.65^{\mathrm{b}}$ \\
\hline S.E. & \pm 25.4 & \pm 18.9 & \pm 1.8 & & \pm 1.08 \\
\hline
\end{tabular}

A, b, c, d. Different letters are significantly different between groups at $\mathrm{P} \leq 0.01 \%$

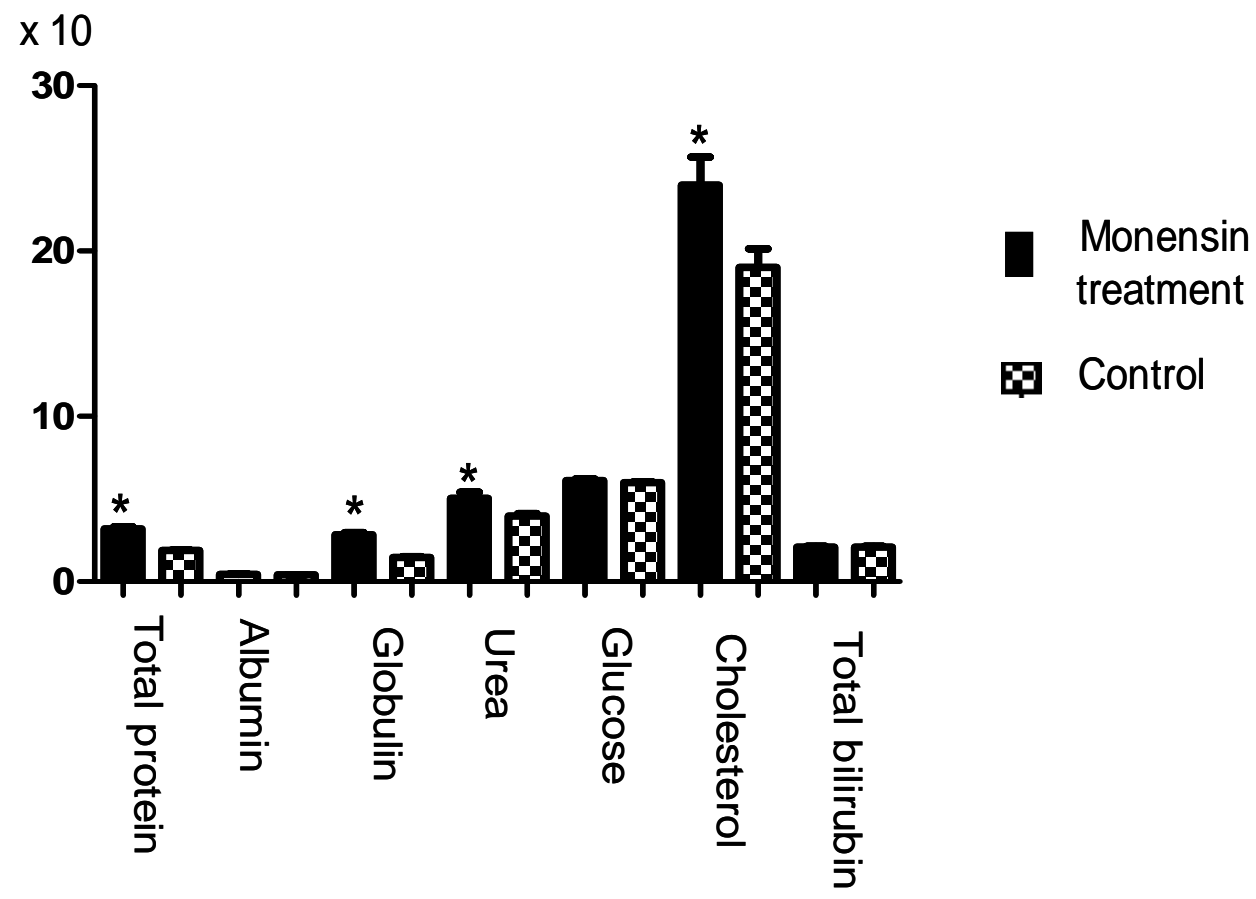

Fig. (1): Showing biochemical changes due to monesin administration at dose of $10 \mathrm{gm} /$ ton for dairy cows 




Fig. (2): Showing the effect of monensin adminsitration at dose of $10 \mathrm{gm} / \mathrm{ton}$ on body weights and daily milk yeild of dairy cows.

Fig. 3: Lymphocyte of dairy cattle treated with monensin show no change at dose of $10 \mathrm{gm} / \mathrm{ton}$. 


\section{DISCUSSION}

Rumensin (monensin) is the first ionophore to be approved by the Food and Drug Administration (FDA) for increased milk production efficiency (production of marketable $4.0 \%$ solids-corrected milk per unit of feed intake) when fed to dairy cows.

There are a closely link between the amount of feed consumed and amount of milk production (Britt $e t$ al., 2004).

The current study supports earlier trials, which established that the inclusion of monensin in dairy cows diets would increase milk yield (Lean and Wade, 1997). The likely mechanism of action to support additional milk yield is that monensin increased the supply of glucogenic precursors resulting from changes in pattern of rumen fermentation.

Increases in blood urea nitrogen due to monensin in dairy cows have been reported previously (Duffield et al., 2012). These studies had much larger sample sizes, which could explain why they obtained significant increases, whereas only numeric increases were observed in our study. Duffield et al. (2012) suggests that this increase is due to a greater supply of bypass protein to the small intestine and a subsequent increase in the use of absorbed nonessential AA for gluconeogenesis. This would lead to a rise in deamination of these AA and higher concentration of BUN. The significant increase in apparent digestibility postcalving and the numeric increase in this digestibility precalving found in our study supports this theory. Also this result agreed with Haimoud et al. (1995) who investigated the effect of monensin $(33 \mathrm{ppm})$ on nitrogen, starch and fibre digestion in the lactating and dried dairy cows and found that compared with control cows, monensin reduced rumen degradation of protein allowing greater flow of amino acids to the small intestine. In the same hand, increased milk and blood urea concentration resulted because both parallel dietary Crud Protein content (Broderick and Clayton, 1997).

There is no effect of monensin on glucose level in our work and these results could attributed to glucose precursors, primarily propionate and amino acids, become essential for a successful lactation. Most of this glucose is produced by liver, and propionate is the single largest contributor to liver glucose production. Glucose synthesis must increase to meet the needs of lactose synthesis. Lactose concentration is fairly constant in milk. Glucose is also used to generate reducing equivalents for the synthesis of milk fat (Angel, 2005). Glucose concentrations were not significantly affected by monensin in the current study. This result agree with Mullins et al. (2012) who found that monensin supplementation had no effect on plasma glucose and insulin level dairy cows.
However, numerical trends support previous studies. There may have been a lack of power to illustrate significant effects in the current project. Stephenson et al. (1997) disagreed with our study and reported that monensin treated-cows had significantly lower glucose values in the immediate precalving period. Other researchers have reported significantly higher glucose concentrations in monensin treated cows postcalving (Duffield et al., 2012).

The higher cholesterol values suggest that there is greater lipoprotein export from the liver (Gerloff et al., 1986; Kaneene et al., 1997). The data are consistent with Green et al. (1999) who reported a tendency for lower serum $\beta$-hydroxybutyrate concentrations during the last 2 wks precalving in cows treated with a monensin at 3 wks before expected calving compared with placebo treated-cows. The data are also supported by Stephenson et al. (1997), who reported that monensin treated-cows had significantly lower $\beta$-hydroxybutyrate and non esterified fatty acids values precalving. However, those data were generated in only 24 cows from two dairy farms and they were managed under a pasture feeding system. This finding was attributed to improved liver function through reduced liver fat deposition. In the current study the results reflect less fat transported to the liver (lower nonesterified fatty acids precalving) combined with greater fat export from the liver (higher cholesterol) which supports the hypothesis that monensin inhibits accumulation of triglycerides in the liver of peripartum dairy cows.

There was a significant increase in body weight of dairy cows treated with monensin and these result could be attributed to Monensin shifts the microbial population in the rumen by promoting the growth of more efficient bacteria involved in carbohydrate metabolism. This results in an increase in propionate production in the rumen (Russell, 1989). Thus, more energy is obtained from every pound of feed. Also increase feed efficiency through increase feed digestibility and this agreed with Duffield et al. (2012) suggests that this increase is due to a greater supply of bypass protein to the small intestine and a subsequent increase in the use of absorbed nonessential AA for gluconeogenesis. This would lead to a rise in deamination of these AA and higher concentration of BUN. The significant increase in apparent digestibility postcalving and the numeric increase in this digestibility precalving found in our study supports this theory. In contrast, Rumensin has been shown to reduce ammonia production and microbial populations in vitro; thus, it would be assumed to reduce ruminal ammonia production and subsequent urea production and consequently affect urea recycling (Recktenwald et al., 2013).

Notably, monensin had stronger antimethanogenic effects in beef steers than dairy cows, but the effects 
in dairy cows could potentially be improved by dietary compos tion modifications and increasing the monensin dose (Grainger et al., 2010 and Appuhamy et al., 2013)

Finally, the present study showed that lymphocyte of dairy cattle treated with monensin show no chromosomal aberration at dose of $10 \mathrm{gm} /$ ton. This result was agree with report of Veterinary medicine and European medicine agency, 2007 for inspection of products for veterinary use.

\section{Author contributions}

1) All Authors make substantial contributions to conception and design, and/or acquisition of data, and/or analysis and interpretation of data;

2) Elalfy mahmoud who participate in drafting the article or revising it critically for important intellectual content

3) Elalfy mahmoud who give final approval of the version to be submitted and any revised version.

\section{ACKNOWLEDGMENTS}

Thanks more for Mr/ EL-Said Sand for his allowance to made this experiments in his dairy farm on Damita governorate. Also grateful thanks for medical Research experimental center who support us on cultivation of lymphocyte.

\section{CONCLUSION}

Any improvement in the conversion of feed to milk has a direct impact on the profit margin of the dairy farm. Our study found that monensin treatment at dose of $10 \mathrm{gm} /$ ton in total mixed ration lead to increase both milk production and body weight through its effect on increase feed digestibility, microbial digestion and also decrease losses of nitrogen in feces which lead to decrease environmental hazards of nitrogen on both animal and public health. More over there is no cytotoxicity recorded due to monensin treatment.

\section{REFERENCES}

Appuhamy, JA .; Strathe, AB.; Jayasundara, S.; Wagner-Riddle, C.; Dijkstra, J.; France, J. and Kebreab, E. (2013): Anti-methanogenic effects of monensin in dairy and beef cattle: a meta-analysisJ Dairy Sci. Aug; 96 (8): 516173.

Angel, (2005): Milk Production Efficiency in Dairy Cows Fed Monensin. Aguilar, Proc. Southwest Nutr. Conf. 192-196b.

Beckett, S.; Lean, 1.I.; Dyson, R.; Tranter, W. and Wade, I. (1998): Effects of Monensin on the Reproduction, Health, and Milk Production of Dairy Cows. J. Dairy Sci. 81.1563-1573.
Britt, J.S.; Thomas, R.C.; Speer, N.C. and Hall, M.B. (2004): Efficiency of converting nutrient drymatter to milk in Holstein herds Journal of Dairy Science 86. 3796-3801. Gaines, W.E.

Broderick, G.A. and Clayton., M.K. (1997): A statistical evaluation of animal and nutritional factors influencing concentrations of milk urea nitrogen. J. Dairy Sci. 80. 2964-2971.

Dubuc, J ${ }^{1}$.; DuTremblay, D.; Baril, J.; Bagg, R.; Brodeur, M.; Duffield, T. and DesCôteaux, L. (2010): A field study on the effects of dietary monensin on milk production and milk composition in dairy cows. Can Vet. J. 2010 Apr; 51(4): 375-9.

Doumnas, B. et al. (1971): A colorimetric method for determination of albumin chem. Acta.

Duffield, $T F^{l}$; Rabiee, A. and Lean, IJ. (2012): Overview of meta-analysis of monensin in dairy cattle. Vet. Clin North Am Food Anim Pract. 28(1):107-19, ix. doi: 10.1016.

Emmerich, IU. (2013): New drugs for horses and production animals in Tierarztl Prax Ausg G Grosstiere Nutztiere. 2014 Aug 14;42(4): 225-30.

Gerloff, B.J.; Herdt, T.H. and Emery, R.S. (1986): Relationship of hepatic lipidosis to health and performance in dairy cattle. JAVMA 188. 845-850.

Grainger, $C^{l}$; Williams, R.; Eckard, RJ. and Hannah, MC. (2010): A high dose of monensin does not reduce methane emissions of dairy cows offered pasture supplemented with grain. J. Dairy Sci. Nov; 93(11): 5300-8.

Granzin, B.C. and Dryden, G.M.C.L. (1999): The effects of monensin on milk production and levels of metabolites in blood and rumen fluid of Holstein-Friesian cows in early lactation. Australian Journal of Experimental Agriculture 39. 933-940.

Green, B.L.; McBride, B.W.; Sandals, D.; Leslie, K.E.; Bagg, R. and Dick, P. (1999): The impact of a monensin controlled-release capsule on subclinical ketosis in the transition dairy cows. J. Dairy Sci. 82. 333-342.

Hamilton, SW ${ }^{I}$; DePeters, EJ.; McGarvey, JA.; Lathrop, J. and Mitloehner, FM. (2010): Greenhouse gas, animal performance, and bacterial population structure responses to dietary monensin fed to dairy cows. Environ Qual. 30; 39(1): 106-14.

Haimoud, D.A.; M. Verney, C. Bayourthe, C. and Montcoulon, R. (1995): Avoparcin and monensin effects on the digestion of nutrients in dairy cows fed amixed diet. Can. J. Anim. Sci. 75. 379-385

Henry, R.J. (1964): Clinical chemistry, Harber \& Row Publishers, New York p. 181.

Jendrassik, L. and Grof, P. (1938): A colorimetric method for determination of bilirubin. Biochem. 7297, 61, 1938. 
Kaplan, L.A. (1984): Glucose. Clin Chem the C.V. Mosby CO. St Louis. Toronto. Princeton 1984; 1032-1036.

Kaneene, J.B.; Miller, R.; Herdt, T.H. and Gardiner, J.C. (1997): The association of serum NEFA and cholesterol, management and feeding practices with periparturient disease in dairy cows. Prev. Vet. Med. 31. 59-72.

Lean, I.J. and Wade, L. (1997): Effects of monensin on metabolism, production, and health of dairy cattle. Pages 50-70 in Usefulnessof Ionophores in Lactating Dairy Cattle. K.L. Leslie, ed. Univ. Guelph, Canada.

McGarvey, JA ${ }^{l}$.; Hamilton, SW.; DePeters, EJ. and Mitloehner, FM. (2010): Effect of dietary monensin on the bacterial population structure of dairy cattle colonic contents. Appl Microbiol Biotechnol. Feb; 85(6): 1947-52.

Mullins, CR ${ }^{l}$; Mamedova, LK.; Brouk, MJ.; Moore, CE.; Green, HB.; Perfield, KL.; Smith, JF.; Harner, JP. and Bradford, BJ. (2012): Effects of monensin on metabolic parameters, feeding behavior, and productivity of transition dairy cows. J. Dairy Sci. Mar; 95(3): 1323-36.

Naito, H.K. and Kaplan, A. (1984): Cholesterol. Clin Chem the C.V. Mosby CO. St Louis. Toronto. Princeton 1984; 1194-11206 and 437.
NRC. (2001): Nutrient Requirements of dairy Cattle. 7th ed. Natl. Acad. Press, Washington, DC.

Patton, C.J. and Crouch, S.R. (1977): A colorimetric method for determination of serum urea. Anal. Chem., 1977. 49. 464-469.

Raun, A.P. (1990): Rumensin then and now. In Rumensin in the 1990s. Elanco Animal Health, Indianapolis, pp A1-A20.

Russell, JB. and Strobel, HJ. (1989): Effect of ionophores on ruminal fermentation. Appl Environ Microbiol; 55. 1-6.

Recktenwald, EB ${ }^{l}$.; Ross, $D A^{l}$.; Fessenden, $S W^{l}$.; Wall, $\mathrm{CJ}^{l}$. and Van Amburgh, $\mathrm{ME}^{2}$ (2013): Urea-N recycling in lactating dairy cows fed diets with 2 different levels of dietary crude protein and starch with or without monensin. J. Dairy Sci. Mar; 97(3): 1611-22. doi:

Stephenson, K.A.; Lean, I.J.; Hyde, M.L.; Curtis, M.A.; Garvin, J.K. and Lowe, L.B. (1997): Effects of monensin on the metabolism of periparturient dairy cows. J. Dairy Sci. 80. 830837.

Veterinary medicine and euroean medicine agency (2007): Inspection products for veterinary use (monensin) EMEA/CVMP/185123 -FINAL.

Thornton, J.H. and Owns, F.N. (1981): Monensin supplementation and invivo methan production by steers. J. Animal SCI 52, 628-634.

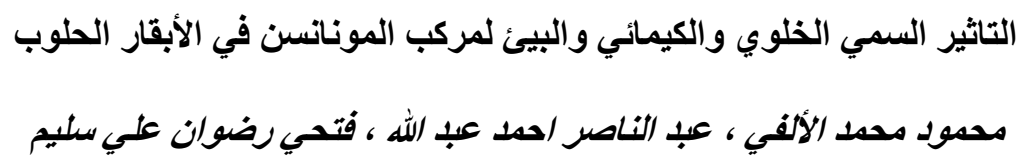

Email: dr_melalfym@yahoo.com

Assiut University web-site: www.aun.edu.eg

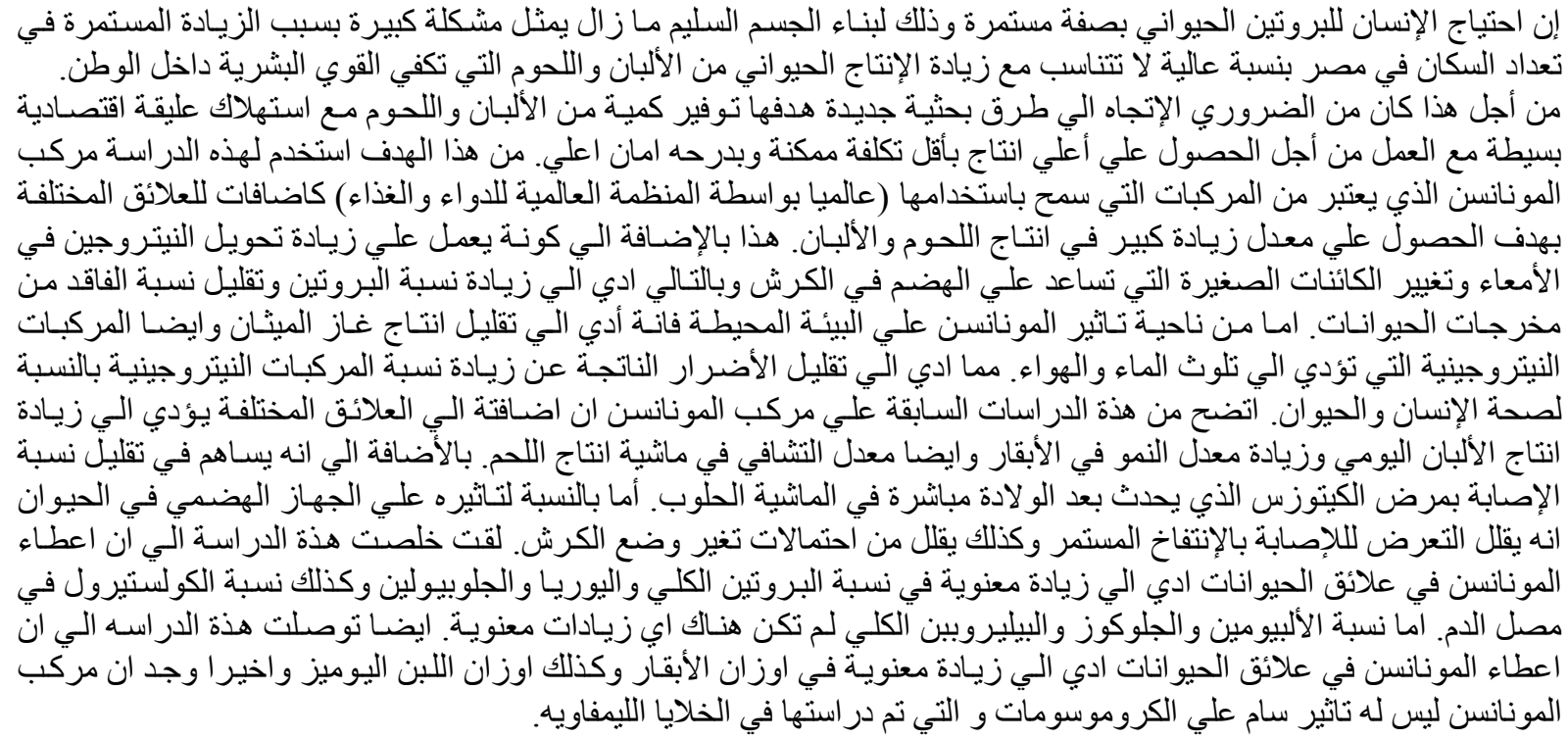

